\title{
ALGINATE BASED GASTRO-RETENTIVE RAFT FORMING TABLETS FOR ENHANCED BIOAVAILABILITY OF TINIDAZOLE
}

\author{
SREEJAN MANNA*, KANCHI JAYASRI, KANCHERLA RADHA ANNAPURNA, LAKSHMI KANTA KANTHAL \\ Koringa College of Pharmacy, Korangi 533461, Tallarevu (M), E. G. DT., Andhra Pradesh, India \\ Email: manna.sreejan@gmail.com
}

Received: 19 Oct 2016, Revised and Accepted: 02 Dec 2016

\section{ABSTRACT}

Objective: Tinidazole, a nitroimidazole derivative is having low aqueous solubility which is a major barrier for systemic drug absorption. The aim of the present research was to develop gastro retentive raft forming tablets of tinidazole to achieve prolonged gastric residence time and thus higher bioavailability.

Methods: Solid dispersion of tinidazole was prepared by kneading method by using methanol and polyvinylpyrrolidone (PVP). Different concentration of sodium alginate and hydroxypropyl methylcellulose (HPMC) was used to formulate a suitable raft forming tablets and then evaluated for drug content, floating lag time, raft strength, raft volume, raft weight, drug release and release kinetics.

Results: Fourier transform infra-red (FT-IR) study confirms compatibility between drug and polymer. The floating lag time was found in the range of $40 \pm 4$ to $60 \pm 5 \mathrm{~s}$ for all the formulation. Raft strength for all the formulations was within the range from $3.03 \pm 0.12$ to $5.92 \pm 0.06 \mathrm{~g}$. The raft volume for all the formulation was found within the range of $7.37 \pm 1.86$ to $9.84 \pm 2.76 \mathrm{ml}$. Raft weight was measured after completion of raft formation for each formulation and was found in the range of $5.21 \pm 1.17$ to $7.88 \pm 1.95 \mathrm{~g}$. In vitro dissolution was carried up to $8 \mathrm{~h}$ and percentage of drug release was found to vary between $79.71 \pm 2.18$ to $94.32 \pm 1.79 \%$.

Conclusion: It can be concluded that the combination of solid dispersion and raft formation increases the bioavailability of tinidazole in tablet formulation.

Keywords: Tinidazole, Raft, Sodium alginate, HPMC, Solid dispersion

(C) 2016 The Authors. Published by Innovare Academic Sciences Pvt Ltd. This is an open access article under the CC BY license (http://creativecommons.org/licenses/by/4.0/) DOI: http://dx.doi.org/10.22159/ijap.2017v9i1.15757

\section{INTRODUCTION}

Oral administration is the most convenient route for any drug delivery to the systemic circulation with high patient compliance and flexibility in formulation [1, 2]. The conventional oral dosage form shows limited bioavailability due to fast gastric emptying [3, 4]. Gastro retentive drug delivery systems are the systems which are retained in the stomach for a longer period of time and thereby improve the bioavailability of drugs [5]. If the drugs are poorly soluble in the intestine due to alkaline $\mathrm{pH}$, gastric retention may increase solubility before they are emptied, resulting in gastrointestinal absorption of drugs with narrow therapeutic absorption window, as well as controlling the release of a drug having site specific absorption limitation [6].

Raft-forming systems [7] have a carbonate components and upon reaction with gastric acid, bubbles form in gel, enabling the floating $[8,9]$. The floating behaviour of the raft is obtained by the buoyancy and low density created by carbon dioxide formation. The mechanism involves the formation of cohesive gel in contact with gas fluids wherein each portion of liquid swells forming a continuous layer called raft. The system contains a gel forming agent (e. g. alginic acid) and sodium bicarbonate which forms a foaming sodium alginate gel (raft) when in contact with gastric fluids [10]. In the presence of gastric acid, the bicarbonate is converted to carbon dioxide which becomes entrapped within the gel precipitate, converting it into foam which floats on the surface of the gastric contents, much like a raft on water $[8,11]$.

Tinidazole, a derivative of 2-methylimidazole chemically known as 1-[2-(ethyl sulphonyl) ethyl]-2-methyl-5-nitroimidazole is a systemic anti-protozoal agent [12]. Tinidazole is widely used for the treatment of trichomoniasis, giardiasis [13] and paediatric patients older than three years of age and for the treatment of intestinal amebiasis and amebic liver abscess caused by E. histolytica. Being a class II drug, tinidazole is having low aqueous solubility which is a major barrier for systemic drug absorption [14]. Among all the solubility enhancement method, solid dispersion is the most popular and simple method $[15,16]$. For the dissolution rate limited system, solid dispersion technique is used widely. Use of different polymers and sugars and numerous techniques of solid dispersion have made this method a useful tool for enhancing bioavailability [17]. Therefore, an attempt has been made in the present research to study the efficacy of solid dispersed tinidazole in raft forming tablets.

\section{MATERIALS AND METHODS}

\section{Materials}

Tinidazole was obtained as a gift sample from Sanroz Lifescience, Ahmedabad, India. Sodium alginate and sodium bicarbonate was commercially purchased from SD fine chemicals, Mumbai. HPMC was obtained as a gift sample from Alembic Ltd, Vadodara. PVP was procured from Nice Chemicals Pvt. Ltd, Kochi. All the chemicals used were of analytical grade.

\section{Methods}

\section{Compatibility study using FT-IR}

Fourier transform infra-red (FTIR) spectroscopy has been used to study the physical and chemical interactions between drugs and excipients. FT-IR spectra were recorded with FT-IR (ATR) spectrophotometer (Bruker Alpha E). Each sample grounded and mixed with potassium bromide (KBr) (Uvasol, Merck, and KgaA, Germany). Pellets were prepared by using a hydraulic press with a pressure of $100 \mathrm{Kg} / \mathrm{cm}^{2}$ for $15 \mathrm{~min}$. The pellets were then scanned from 4000 to $400 \mathrm{~cm}^{-1}$ with a mirror speed of $2 \mathrm{~mm} / \mathrm{s}$. Drugexcipient compatibility study was carried out by FT-IR analysis of pure tinidazole, sodium alginate, HPMC, PVP, a solid dispersion of tinidazole, and a formulation containing tinidazole.

\section{Formulation of solid dispersion of tinidazole}

The solid dispersion of tinidazole was prepared by kneading method by using methanol as a solvent $[17,18]$. The mixture of tinidazole and PVP was wetted with methanol and kneaded thoroughly in a glass mortar for $20 \mathrm{~min}$. The resulted homogenous mixture was 
dried at $40^{\circ} \mathrm{C}$ in a hot air oven for $24 \mathrm{~h}$. The formulated powder was sieved through 60 mesh sieve and stored in a vacuum desiccator.

\section{Preparation of tinidazole raft forming tablets}

Six different raft forming tablets were prepared by varying the concentrations of polymers. All the ingredients, in which the polymers sodium alginate, HPMC, anhydrous lactose, sodium bicarbonate, tartaric acid and were weighed individually and shifted manually through mesh \# 40 separately. Thereafter, tinidazole, sodium bicarbonates, lactose and PVP were mixed separately for 5 min. Talc and magnesium stearate were finally added as a lubricant and then mixed for further $5 \mathrm{~min}$. The weight of the tablet was determined as $500 \mathrm{mg}$ and the tablets were compressed using a punch and die set to produce round shaped tablets [19].

Table 1: Formulation of tinidazole raft forming tablets

\begin{tabular}{|c|c|c|c|c|c|c|}
\hline Ingredients (mg) & F1 & F2 & F3 & F4 & F5 & F6 \\
\hline Drug (tinidazole) or solid dispersed tinidazole equivalent to & 100 & 100 & 100 & 100 & 100 & 100 \\
\hline Sodium alginate & 140 & 140 & 160 & 180 & 190 & 200 \\
\hline HPMC & 140 & 100 & 80 & 60 & 50 & 40 \\
\hline PVP & - & 100 & 100 & 100 & 100 & 100 \\
\hline Sodium bicarbonate & 20 & 20 & 20 & 20 & 20 & 20 \\
\hline Lactose & 40 & - & - & - & - & - \\
\hline Tartaric acid & 20 & 20 & 20 & 20 & 20 & 20 \\
\hline Talc & 10 & 10 & 10 & 10 & 10 & 10 \\
\hline Magnesium stearate & 10 & 10 & 10 & 10 & 10 & 10 \\
\hline
\end{tabular}

\section{Evaluation of pre-compression parameters for powder blend}

All the pre-compression parameters like bulk density, tapped density, angle of repose, Carr's index, Hausner's ratio were measured according to standard procedure [20].

\section{Evaluation of post-compression parameters of tinidazole raft forming tablets}

\section{Tablet thickness}

The thickness of the prepared tinidazole tablets was measured by using Vernier calliper (Acculab, Ambala, India) in mm. Five tablets from each formulation were selected randomly and used for thickness test.

\section{Hardness test}

Hardness test was carried out by using "Monsanto" hardness tester with randomly selected five tablets by fitting them sufficiently between the spindle and the anvil through their diameter. Then the pressure on the tablet is increased by turning the knurled knob until the tablet breaks. The force (in $\mathrm{Kg}$ ) required to break the tablet is noted from the scale.

\section{Friability test}

The friability of the prepared tablets was measured by "Roche" friabilator. 10 tablets were weighted and placed in the plastic chamber of friabilator and set for $25 \mathrm{rpm}$ for about $4 \mathrm{~min}$ and the tablets were removed, de-dusted and reweighed. The percentage of friability was calculated as per formula [21].

$$
\% \text { Friability }=\frac{\text { Initial weight }- \text { Final weight }}{\text { Initial weight }} \times 100
$$

\section{Weight variation test}

Twenty tablets were selected at random, and the average weight was determined. Not more than two of the individual tablets weights should deviate from the average weight by more than $7.5 \%$ deviation and none should deviate by more than twice the percentage.

\section{Disintegration test}

Disintegration test for the prepared tinidazole raft forming tablets was performed in a tablet disintegration test apparatus (Electronics India 901 , India) in simulated gastric fluid at $37+0.5^{\circ} \mathrm{C}$.

\section{Drug content uniformity}

10 randomly selected tablets were weighed and powdered by using a glass mortar and pestle [22]. A powder quantity equivalent to 50 mg was taken and dissolved in $100 \mathrm{ml}$ of $0.1 \mathrm{~N} \mathrm{HCl}$ buffer. From the above solution, $1 \mathrm{ml}$ was taken out and diluted with $9 \mathrm{ml}$ of $0.1 \mathrm{~N} \mathrm{HCl}$ buffer. Then the solution was filtered with the help of a Whatman filter paper. The absorbance of the filtered solution was measured by using a UV-VIS spectrophotometer (Elico Lab, SL 210) at $\lambda_{\max } 286$ $\mathrm{nm}$ and the drug content was calculated by the following equation-

$\%$ Drug content

$=\frac{\text { Actual tinidazole content in weighed quantity of tablets }}{\text { Theoritical amount of tinidazole present in taken tablets }}$
$\times 100$

\section{Floating lag time}

Floating lag time or buoyancy test was carried out in a $100 \mathrm{ml}$ beaker containing $0.1 \mathrm{~N} \mathrm{HCl}$ buffer $\mathrm{pH}$ 1.2. The tinidazole raft forming tablets were placed in the beaker and the time required to rise to the surface was determined as floating lag time [23].

\section{Raft strength measurement by in-house method}

Raft strength for the prepared tinidazole tablets was determined by modified physical balance method. Raft-forming tablets were placed into $250 \mathrm{ml}$ beakers containing $150 \mathrm{ml}$ of $0.1 \mathrm{~N} \mathrm{HCl}$ buffer maintained at $37.4 \pm 0.5{ }^{\circ} \mathrm{C}$. An L-shaped stainless steel wire probe (length $=9 \mathrm{~cm}$, diameter $1.2 \mathrm{~mm}$ ) was partially dipped into each beaker. The wire probe was held firmly during the period of raft formulation (30 $\mathrm{min}$ ) allowing the raft to form around it. After completion of raft formulation, the wire probe was connected with one arm of a double pan dispensing balance. Water was added dropwise to the pan and the weight of water required to break the raft was recorded [24].

\section{Raft volume and raft weight determination}

Raft-forming tablet was placed inside a pre-weighed $\left(\mathrm{W}_{1} \mathrm{~g}\right)$ glass beaker containing $150 \mathrm{ml} \mathrm{HCl}$ buffer just like the above procedure but without any wire. The beaker was kept undisturbed for $30 \mathrm{~min}$ for completion of raft formation. When the raft formation was completed, the position up to which the top of each raft has reached was marked from outside. After raft development, the total weight of the beaker was measured again $\left(\mathrm{W}_{2} \mathrm{~g}\right)$. Then the raft was carefully separated and kept in a plastic pre-tared weighing boat. The raft was allowed to stand for $1 \mathrm{~min}$ and any trace of subnatant liquid was carefully taken out. The weight of the raft was measured accurately $\left(\mathrm{W}_{3} \mathrm{~g}\right)$. Any trace of water was wiped off from the beaker and it was refilled with water up to the previous mark and weighed $\left(\mathrm{W}_{4} \mathrm{~g}\right)$ [24]. The raft volume was calculated from the following formula by assuming that the density of subnatant liquid is similar to water-

$$
\text { Raft volume }=\left(W_{4}-W_{1}\right)-\left(W_{2}-W_{1}-W_{3}\right)
$$

\section{In vitro drug release studies}

The release of drug from different batches for the prepared tinidazole raft forming tablets was studied by using USP type II paddle type dissolution apparatus (Lab India DS 8000). The dissolution medium used was $900 \mathrm{ml}$ of $0.1 \mathrm{~N} \mathrm{HCl}$ buffer. The temperature was maintained 
at $37{ }^{\circ} \mathrm{C} \pm 0.5{ }^{\circ} \mathrm{C}$ with continuous stirring at a rate of $50 \mathrm{rpm} .5 \mathrm{ml}$ samples were withdrawn at regular time intervals and the same volume was replaced with fresh dissolution medium to maintain the sink condition. The absorbance was measured by UV-VIS spectrophotometer (ELICO SL 210) at $286 \mathrm{~nm}$. Dissolution studies were performed for a period of $8 \mathrm{~h}$ for all the formulations, and the cumulative percentage release of drug was calculated [25].

\section{Release kinetics}

In order to understand the mechanism and kinetics of drug release, the result of the in vitro dissolution study of formulated particle were fitted with various kinetic equations, such as zero-order, firstorder, Higuchi's model, Korsmeyer-Peppas model and Hixon-Crowell model [26]. Correlation coefficient $\left(\mathrm{R}^{2}\right)$ values were calculated for the linear curves obtained by regression analysis of the above plots.

\section{Zero order kinetics}

The zero order describes the systems where the drug release rate is independent of its concentration.

A zero order release would be predicted by the following equation,

$$
\mathrm{Q}_{\mathrm{t}}-\mathrm{Q}_{0}=\mathrm{K}_{0} \mathrm{t}
$$

Where,

$\mathrm{Q}_{\mathrm{t}}=$ Amount of drug release dissolved in time ' $\mathrm{t}$ '.

$\mathrm{Q}_{0}=$ Initial amount of drug concentration in solution.

$\mathrm{K}_{0}=$ Zero order rate constant.

When the data was plotted as cumulative $\%$ drug release $V_{s}$ time, if the plot is linear then data obeys zero order kinetics with slope equal to $\mathrm{K}_{0}$. This model represents an ideal release profile in order to achieve the prolonged pharmacological action [26].

\section{First order kinetics}

The first order describes the release from a system where release rate is concentration dependent.

A first order release would be predicted by the following equation

$$
\log Q_{t}=\log Q_{0}-\frac{K_{1} t}{2.303}
$$

Where,

$Q_{t}=$ Amount of drug released at time ' $t$ '.

$\mathrm{Q}_{0}=$ Initial amount of drug concentration in solution.

$\mathrm{K}_{1} \mathrm{t}=$ First order rate constant

When data was plotted as log cumulative $\%$ drug remaining $\mathrm{V}_{\mathrm{s}}$ time yields a straight line indicating that the release follows first order kinetics. The constant $\mathrm{K}$ can be obtained multiplying slope values [26].

\section{Higuchi's model}

Higuchi (1963) described the release of drugs from the insoluble matrix as a square root of time dependent process based on Fickian diffusion [26]. The graph was plotted as \% cumulative drug released Vs square root of time.

$$
\mathrm{Q}=\mathrm{Kt}^{0.5}
$$

Where,

$\mathrm{K}=$ Constant reflecting design variable system

$$
\mathrm{t}=\text { time in } \mathrm{h}
$$

\section{Korsmeyer-peppas}

Korsmeyer et al. (1983) derived a simple relationship which described drug release from a polymeric system. To find out the mechanism of drug release, first, $60 \%$ drug release data was fitted in Korsmeyer-Peppas model.

To evaluate the mechanism of drug release, it was further plotted in Peppas equation as log cumulative $\%$ of drug released $\mathrm{V}_{\mathrm{s}}$ time.

$$
\begin{gathered}
\mathrm{M}_{\mathrm{t}} / \mathrm{M}_{\alpha}=\mathrm{Kt}^{\mathrm{n}} \\
\log \mathrm{M}_{\mathrm{t}} / \mathrm{M}_{\alpha}=\log \mathrm{K}+\mathrm{n} \log \mathrm{t}
\end{gathered}
$$

Where,

$\mathrm{M}_{\mathrm{t}} / \mathrm{M}_{\alpha}=$ fraction of drug released at time $\mathrm{t}$

$\mathrm{t}=$ Release time

$\mathrm{K}=$ Kinetic constant

$\mathrm{n}=$ Diffusional exponent indicative of the mechanism drug.

This model is used to analyse the release of pharmaceutical polymeric dosage forms depending on ' $n$ ' value when the release mechanism is not known or more than one type of release phenomenon was involved. $\mathrm{n} \leq 0.43$ symbolise Fickian release, $0.43<n<0.85$ symbolise non-Fickian release and $n \geq 0.85$ indicates a case II transport [26].

\section{Hixson-Crowell model}

The Hixson-Crowell model describes the release from systems where there is a change in surface area and diameter of particles or tablets [26].

$$
Q_{t}^{1 / 3}-Q_{t}^{1 / 3}=K_{H C} t
$$

Where,

$\mathrm{Q}_{\mathrm{t}}=$ Remaining amount of drug in the dosage form at time $\mathrm{t}$,

$\mathrm{Q}_{0}=$ Initial amount of the drug in the tablet

$\mathrm{K}_{\mathrm{HC}}=$ Rate constant for Hixson-Crowell rate equation

\section{RESULTS AND DISCUSSION}

\section{Fourier transform infra-red spectroscopy (FT-IR)}

FTIR spectrum of tinidazole, solid dispersion of tinidazole, sodium alginate, HPMC, PVP and formulation were shown in fig. 1. FTIR spectrum of tinidazole shows a peak at $3290.81 \mathrm{~cm}^{-1}$ for aromatic C$\mathrm{H}$ stretching which can be observed in the formulation $(3286.81 \mathrm{~cm}$ 1) and solid dispersion of drug $\left(3283.08 \mathrm{~cm}^{-1}\right)$. Peaks for $\mathrm{C}-\mathrm{H}$ stretching for alkane shows a peak at $3030.34 \mathrm{~cm}^{-1}$ which is observed in the formulation $\left(3103.83 \mathrm{~cm}^{-1}\right)$ and solid dispersion $(3147.87 \mathrm{~cm}$ 1). N-O Symmetric stretching for nitro compound shows a peak at $1296.82 \mathrm{~cm}^{-1}$ which is observed in the formulation $\left(1364.77 \mathrm{~cm}^{-1}\right)$ and solid dispersion $\left(1293.49 \mathrm{~cm}^{-1}\right)$. $=\mathrm{C}-\mathrm{H}$ bending for alkene shows a peak at $688.80 \mathrm{~cm}^{-1}$ which can be observed in the formulation $\left(689.53 \mathrm{~cm}^{-1}\right)$ and solid dispersion $\left(755.70 \mathrm{~cm}^{-1}\right)$. C-C stretching for the aromatic compound is observed at $1448.76 \mathrm{~cm}^{-1}$ which can be

\begin{tabular}{|c|c|c|c|c|}
\hline Formulation code & Thickness* $(\mathrm{mm}) \pm$ SD & Weight variation test $^{* *}(\%) \pm$ SD & Hardness* $\left(\mathrm{Kg} / \mathrm{cm}^{3}\right) \pm S D$ & Friability* $(\%) \pm S D$ \\
\hline F1 & $3.3 \pm 0.089$ & $498 \pm 0.08$ & $5.85 \pm 0.23$ & $0.53 \pm 0.08$ \\
\hline F2 & $3.3 \pm 0.043$ & $497 \pm 1.13$ & $5.74 \pm 0.46$ & $0.49 \pm 0.02$ \\
\hline F3 & $3.2 \pm 0.067$ & $496 \pm 2.03$ & $5.66 \pm 0.66$ & $0.46 \pm 0.07$ \\
\hline $\mathrm{F} 4$ & $3.2 \pm 0.022$ & $495 \pm 1.16$ & $5.78 \pm 0.55$ & $0.52 \pm 0.06$ \\
\hline F5 & $3.2 \pm 0.039$ & $495 \pm 2.12$ & $5.6 \pm 0.62$ & $0.48 \pm 0.07$ \\
\hline F6 & $3.3 \pm 0.088$ & $498 \pm 1.04$ & $5.53 \pm 0.88$ & $0.45 \pm 0.08$ \\
\hline
\end{tabular}
seen in the formulation $\left(1532.75 \mathrm{~cm}^{-1}\right)$ and solid dispersion $\left(1452.66 \mathrm{~cm}^{-1}\right)$. The characteristic peaks appeared in the FT-IR spectrum of tinidazole is observed without any significant shifting of peaks, indicating the absence of any chemical interaction during and after preparation.

Table 2: Post-compression parameters for tinidazole raft forming tablets

${ }^{*} \mathrm{n}=10 ;{ }^{* *} \mathrm{n}=20 ;$ SD-Standard deviation 


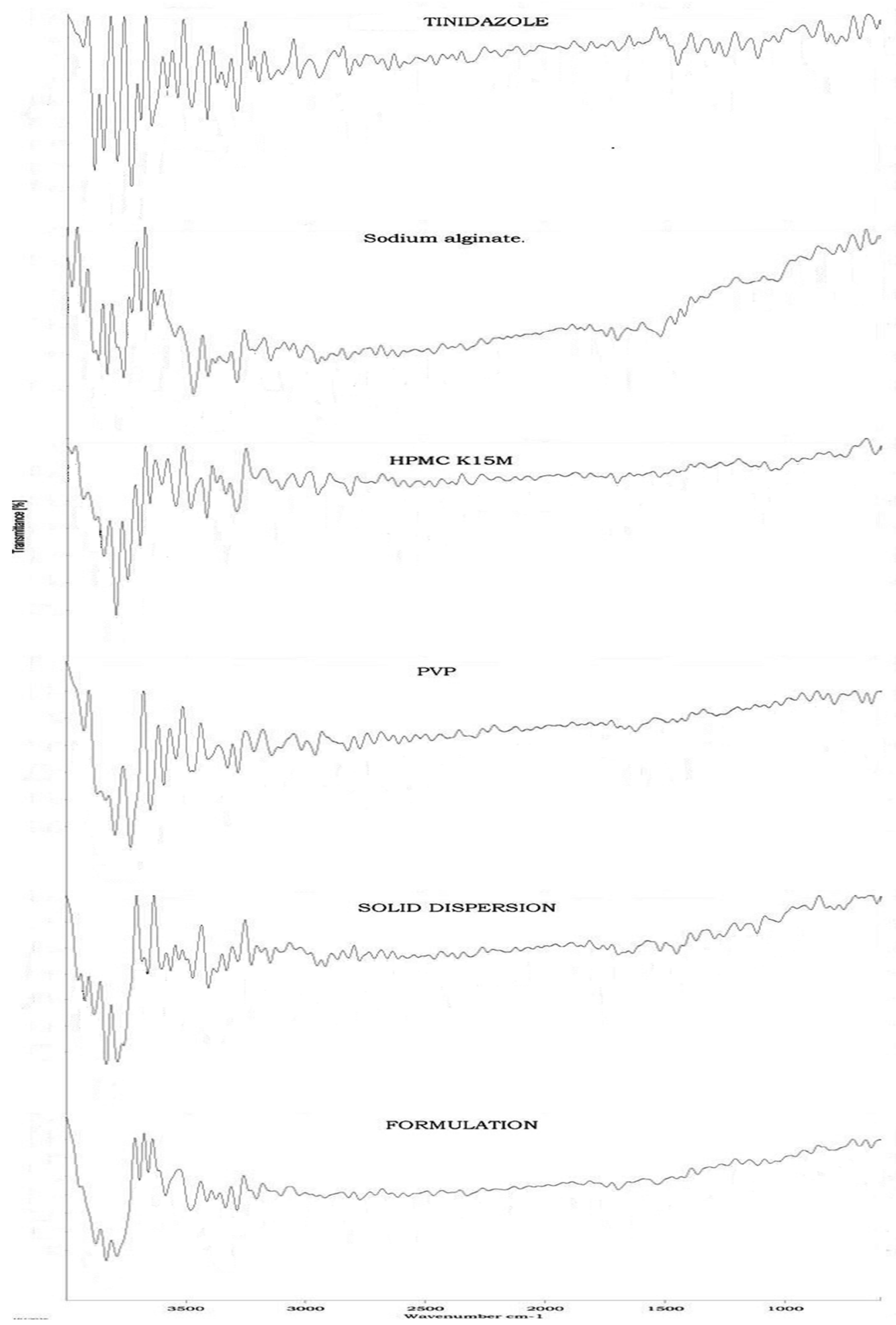

Fig. 1: FTIR spectrum of tinidazole, sodium alginate, HPMC K15M, PVP, solid dispersion of tinidazole and formulation

\section{Disintegration test}

Disintegration time for all the formulations was determined, and the values were within the range from $10 \pm 2 \mathrm{~min}$ to $18 \pm 3 \mathrm{~min}$ (data shown in table 3).

Highest disintegration time was observed for F1 (18 \pm 3 min) which may be due to the higher concentration of HPMC acting as a matrix forming agent. A faster disintegration of tablets has been observed with decrease in HPMC concentration.

\section{Drug content}

The average drug content for each formulation was calculated from the absorbance values. The drug content for the prepared raft forming tablets were found within the range of $98.78 \pm 0.57$ to $99.63 \pm 0.35$ (as shown in table no 3).

\section{Floating lag time}

Floating lag time for all the formulations was determined in $0.1 \mathrm{~N} \mathrm{Hcl}$ buffer, and the values were within the range from $40 \pm 4$ to $60 \pm 5 \mathrm{~s}$ (data shown in table 3). 
Table 3: Various evaluation parameters for tinidazole raft forming tablets

\begin{tabular}{|c|c|c|c|c|c|c|}
\hline $\begin{array}{l}\text { Formulation } \\
\text { code }\end{array}$ & $\begin{array}{l}\% \text { drug content* } \\
\text { mean } \pm \text { SD }\end{array}$ & $\begin{array}{l}\text { Floating lag time* } \\
\text { (s) mean } \pm \text { SD }\end{array}$ & $\begin{array}{l}\text { Disintegration time }{ }^{* *} \\
\text { (min) mean } \pm \text { SD }\end{array}$ & $\begin{array}{l}\text { Raft strength* } \\
\text { mean } \pm \text { SD }\end{array}$ & $\begin{array}{l}\text { Raft weight* } \\
\text { (g) mean } \pm \text { SD }\end{array}$ & $\begin{array}{l}\text { Raft volume* } \\
(\mathrm{ml}) \text { mean } \pm S D\end{array}$ \\
\hline F1 & $98.78 \pm 0.57$ & $60 \pm 5$ & $18 \pm 3$ & $3.03 \pm 0.12$ & $5.21 \pm 1.17$ & $7.37 \pm 1.86$ \\
\hline F2 & $99.08 \pm 0.39$ & $40 \pm 4$ & $16 \pm 2$ & $3.66 \pm 0.16$ & $5.73 \pm 1.64$ & $7.82 \pm 2.13$ \\
\hline F3 & $99.46 \pm 0.42$ & $44 \pm 8$ & $14 \pm 3$ & $3.10 \pm 0.14$ & $5.62 \pm 1.38$ & $7.71 \pm 1.97$ \\
\hline F4 & $98.81 \pm 0.68$ & $50 \pm 3$ & $14 \pm 2$ & $3.95 \pm 0.07$ & $6.57 \pm 1.87$ & $8.63 \pm 2.49$ \\
\hline F5 & $99.24 \pm 0.51$ & $45 \pm 6$ & $11 \pm 2$ & $5.50 \pm 0.11$ & $7.49 \pm 1.36$ & $9.32 \pm 1.84$ \\
\hline F6 & $99.63 \pm 0.35$ & $52 \pm 4$ & $10 \pm 3$ & $5.92 \pm 0.06$ & $7.88 \pm 1.95$ & $9.84 \pm 2.76$ \\
\hline
\end{tabular}

${ }^{*} \mathrm{n}=3$;** $\mathrm{n}=6$; SD-Standard deviation

\section{Raft strength}

Raft strength for all the formulations was within the range from $3.03 \pm 0.12 \mathrm{~g}$ to $5.92 \pm 0.06 \mathrm{~g}$ (data shown in table 3). Among all the formulation, F6 is having maximum raft strength which is achieved by more concentration of sodium alginate. The result clearly indicates that higher concentration of sodium alginate enhances the raft strength of the formulation [24].

\section{Raft volume and raft weight}

The raft volume for all the formulation was found within the range of $7.37 \pm 1.86 \mathrm{ml}$ to $9.84 \pm 2.76 \mathrm{ml}$ (data provided in table 3 ). F1 is observed to have the lowest raft volume $(7.37 \pm 1.86 \mathrm{ml})$, whereas $\mathrm{F} 6$ produced maximum raft volume $(9.84 \pm 2.76 \mathrm{ml})$. A gradual increase in raft volume is observed with increase in s sodium alginate concentration in the formulation which is due to the raft forming capacity of sodium alginate. Similar results were found by Dettmar PW et al. for alginate rafts [24].

Raft weight was measured after completion of raft formation for each formulation and was found in the range of $5.21 \pm 1.17$ to $7.88 \pm 1.95 \mathrm{~g}$. F1 was found to have lowest raft weight among all the formulation and whereas F6 resulted in maximum raft weight. The variation in raft weight was directly proportional to the amount of sodium alginate used in the formulation [24].

\section{In vitro drug release study}

In vitro dissolution of tinidazole, raft forming tablets were carried out in $0.1 \mathrm{~N} \mathrm{HCl}$ buffer solution under sink condition up to 8h. F1 and F2 shown a slow release initially, whereas F3, F4, F5, F6 has shown an initial burst release (data shown in table 4). This phenomenon is observed due to the presence of solid dispersed tinidazole in F3-F6 formulation. The cumulative release of drug was found to vary between $79.71 \pm 2.18$ to $94.32 \pm 1.79 \%$. From the above result, it can be clearly said that the decrease in HPMC concentration is having a positive impact in drug release (fig. 2) due to variation in matrix strength of tablet formulation.

\section{In vitro release kinetics}

The release kinetics of various formulations is described in table 5 . The time to time cumulative percentage release of tinidazole was fitted into different release models: Zero order, First order, Higuchi's plot, Korsmeyer-Peppas and Hixson-Crowell model. The correlation coefficients for all the formulations were calculated from respective graphs. Based on the $\mathrm{R}^{2}$ values, the release mechanism for F1, F2, F5 and F6 were found to follow Korsmeyer-Peppas kinetics for which " $n$ " value was found within the range of $0.27-0.69$, indicating an anomalous release (non-Fickian kinetics corresponding to coupled diffusion/polymer relaxation). F3 and F4 followed Hixson-Crowell release kinetics.

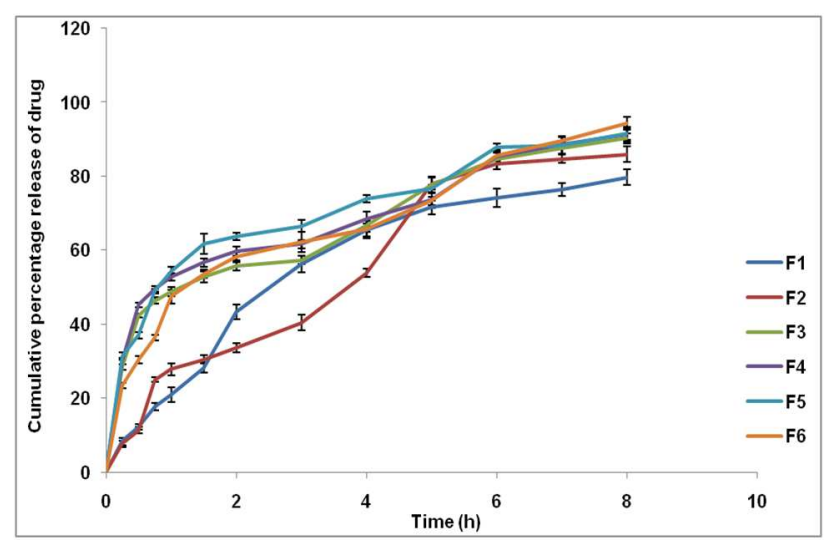

Fig. 2: Comparative C. P. R. of tinidazole from raft forming tablets

Table 4: In vitro drug release for all the formulations of tinidazole raft forming tablets

\begin{tabular}{llllll}
\hline Time (h) & F1 & F2 & F3 & F4 & F5 \\
& C. P. R. \pm SD & C. P. R. \pm SD & C. P. R. \pm SD & C. P. R. \pm SD & F6 \\
C. P. R. \pm SD
\end{tabular}

$\mathrm{n}=3$; CPR-Cumulative percentage release; SD-Standard deviation 
Table 5: Results for curve fitting of in vitro release of tinidazole from prepared tablets

\begin{tabular}{|c|c|c|c|c|c|c|c|}
\hline \multirow{2}{*}{$\begin{array}{l}\text { Formulation } \\
\text { code }\end{array}$} & \multirow[t]{2}{*}{ Zero order $\mathbf{R}^{2}$} & \multirow[t]{2}{*}{ First order $\mathbf{R}^{2}$} & \multirow{2}{*}{$\begin{array}{l}\text { Higuchi } \\
\mathbf{R}^{2}\end{array}$} & \multicolumn{2}{|c|}{ Korsmeyer-peppers } & \multirow{2}{*}{$\begin{array}{l}\text { Hixson-crowell } \\
\mathbf{R}^{2}\end{array}$} & \multirow[t]{2}{*}{ Best fit model } \\
\hline & & & & $\mathbf{R}^{2}$ & $\mathbf{N}$ & & \\
\hline F1 & 0.7785 & 0.9698 & 0.9701 & 0.9796 & 0.6984 & 0.9512 & Korsmeyer-Peppas \\
\hline $\mathrm{F} 2$ & 0.8685 & 0.9518 & 0.9554 & 0.9609 & 0.6908 & 0.9566 & Korsmeyer-Peppas \\
\hline F3 & 0.9440 & 0.9712 & 0.8916 & 0.9588 & 0.3009 & 0.9757 & Hixson-Crowell \\
\hline F4 & 0.9260 & 0.9554 & 0.9591 & 0.9528 & 0.2767 & 0.9632 & Hixson-Crowell \\
\hline F5 & 0.8860 & 0.9686 & 0.958 & 0.9705 & 0.2987 & 0.9608 & Korsmeyer-Peppas \\
\hline F6 & 0.0562 & 0.9481 & 0.9737 & 0.9782 & 0.3869 & 0.9691 & Korsmeyer-Peppas \\
\hline
\end{tabular}

\section{CONCLUSION}

Raft-forming tablets of tinidazole were prepared with and without solid dispersion of drug with PVP. The floating lag time was found within the range of $40 \pm 4$ to $60 \pm 5 \mathrm{~s}$. The formation of alginate raft was clearly observed for all the formulation, and the raft strength was found satisfactory. The raft volume and raft weight was measured and found to increase with sodium alginate concentration. The in vitro drug release concluded that after $8 \mathrm{~h}$ of dissolution, the maximum release was observed for F6. It can be evidently said that in raft forming tablets, the dissolution rate for solid dispersed tinidazole has increased effectively. Controlled release of tinidazole is obtained by using a combination of a solid dispersion of drug with PVP and HPMC as a matrix forming agent. The combination of these two resulted in an initial increase in dissolution rate and then a controlled release over $8 \mathrm{~h}$ of time which can facilitate complete absorption of the drug. It can be concluded that the development of a raft-forming system with a solid dispersion of drug is expected to have a positive impact in bioavailability improvement of stomachspecific poorly water soluble drug.

\section{ACKNOWLEDGEMENT}

This work was encouraged and supported by the management of Koringa College of Pharmacy, Korangi, Andhra Pradesh, India.

\section{CONFLICTS OF INTERESTS}

There are no potential conflicts of interests as declared by the authors.

\section{REFERENCES}

1. Nayak AK, Maji R, Das B. Gastroretentive drug delivery systems: a review. Asian J Pharm Clin Res 2010;3:2-10.

2. Mathur P, Saroha K, Syan N, Verma S, Nanda S, Valecha V. An overview on recent advancements and developments in gastro retentive buoyant drug delivery system. Der Pharm Sin 2011;2:161-9.

3. Mudie DM, Amidon GL, Amidon GE. Physiological parameters for oral delivery and in vitro testing. Mol Pharm 2010;7:1388-405.

4. Nayak AK, Malakar J, Sen KK. Gastroretentive drug delivery technologies: current approaches and future potential. J Pharm Edu Res 2010;1:1-12.

5. Govikari KR, Praveen KM, Rajendraprasad M, Veerareddy PR. Development and in vivo evaluation of gastro retentive delivery systems for cefuroxime axetil. Saudi Pharm J 2013;21:53-9.

6. Juan T, Jean-Yves LH, Phillipe M. Narrow therapeutic index drugs: a clinical pharmacological consideration to flecainide. Eur J Clin Pharmacol 2015;71:549-67.

7. Ajay V, Senthilnathan B, Ravichandiran V. A review article on different types of floating drug delivery systems. Int J Pharm Pharm Sci 2012;4:45-50.

8. Mandel KG, Daggy BP, Brodie DA, Jacoby HI. Alginate-raft formulations in the treatment of heartburn and acid reflux. Aliment Pharmacol Ther 2000;14:669-90.

9. Mosab A. Approaches to achieve an oral controlled release drug delivery system using polymers: a recent review. Int J Pharm Pharm Sci 2015;7:16-21.
10. Fabregas J, Claramunt J, Cucala J. In vitro testing of an antacid formulation with a prolonged gastric residence time (Almagate Flot-Coat). Drug Dev Ind Pharm 1994;20:1199-212.

11. Washington N, Greaves JL, Wilson CG. Effect of time of dosing relative to a meal on the raft formation anti-reflux agent. J Pharm Pharmacol 1990;42:50-3.

12. Fung HB, Doan TL. Tinidazole: a nitroimidazole antiprotozoal agent. Clin Ther 2005;27:1859-84.

13. Timothy BG, David RH. Treatment of giardiasis. Clin Microbiol Rev 2001;14:114-28.

14. Ripal G, Hari KA, Ashwin P, Ashim KM. Ocular drug delivery. AAPS J 2010;12:348-60.

15. Swati S, George M, Lincy J. Improvement in solubility of poorly water-soluble drugs by solid dispersion. Int J Pharm Investig 2012;2:12-7.

16. Aejaz A, Azmail K, Sanaullah S, Mohsin AA. Formulation and in vitro evaluation of aceclofenac solid dispersion incorporated gels. Int J Appl Pharm 2010;2:7-12.

17. Ladan AN, Gurinder S, Gaurav S, Kimia FK. Solid dispersion: methods and polymers to increase the solubility of poorly soluble drugs. J Appl Pharm Sci 2012;2:170-5.

18. Sweta KS, Vijay S, Kamla P. Formulation and evaluation of taste masked rapid release tablets of sumatriptan succinate. Int J Pharm Pharm Sci 2012;4:168-74

19. Bajpai M, Singh DCP, Bhattacharya A, Singh A. Design and in vitro evaluation of compression-coated pulsatile release tablets of losartan potassium. Indian J Pharm Sci 2012;74:101-6.

20. Mafalda CS, João AL, Ana VC, Sandra OS, Helena RA, Paulo CC. Determination of flow properties of pharmaceutical powders by near infrared spectroscopy. J Pharm Biomed Anal 2010;52:484-92.

21. Ashwini R, Bushetti SS, Archana Giri. Design and evaluation of compression coated formulations for an anti-inflammatory drug based on modified okra mucilage. J Appl Pharm Sci 2012;2:238-45.

22. Poluri K, Suvarnala S, Puttugunta S, Govada KB, Pinnamraju DN. Formulation development and evaluation of fast disintegrating tablets of lamotrigine using the liquid-solid technique. Int J Pharm Investig 2014;4:207-14.

23. Harshal AP, Rachana D. Development and evaluation of gastro retentive floating tablets of an antidepressant drug by thermoplastic granulation technique. Beni-Seuf Univ J Appl Sci 2014;3:122-32.

24. Dettmar PW, Hampson FC, Farndale A, Strugala V, Sykes J, Jolliffe IG. Alginate rafts and their characterisation. Int J Pharm 2005;294:137-47.

25. Basak SC, Jayakumar RBM, Lucas MKP. Formulation and release behaviour of sustained release ambroxol hydrochloride HPMC matrix tablet. Indian J Pharm Sci 2006;68:594-8.

26. Suvakanta D, Padala NM, Lilakanta N, Prasanta C. Kinetic modelling on drug release from controlled drug delivery systems. Acta Poloniae Pharm Drug Res 2010;67:217-23.

\section{How to cite this article}

- Sreejan Manna, Kanchi Jayasri, Kancherla Radha Annapurna, Lakshmi Kanta Kanthal. Alginate based gastro-retentive raft forming tablets for enhanced bioavailability of tinidazole. Int J Appl Pharm 2017;9(1):16-21. 